\title{
Tetrandrine concentrations not affecting oxidative phosphorylation protect rat liver mitochondria from oxidative stress
}

\author{
Maria A.S. Fernandes ${ }^{\text {a,* }}$, José B.A. Custódio ${ }^{\text {b }}$, Maria S. Santos ${ }^{\text {a }}$, \\ António J.M. Moreno ${ }^{a}$, Joaquim A.F. Vicente ${ }^{\mathrm{c}}$ \\ a Departamento de Zoologia, Faculdade de Farmácia, Universidade de Coimbra, Couraça dos Apóstolos, 51, R/C, 3000-517 Coimbra, Portugal \\ ${ }^{\mathrm{b}}$ Laboratório de Bioquímica, Faculdade de Farmácia, Universidade de Coimbra, Couraça dos Apóstolos, 51, R/C, 3000-295 Coimbra, Portugal \\ ${ }^{\mathrm{c}}$ Departamento de Botânica, Faculdade de Ciências e Tecnologia, Universidade de Coimbra, 3004-517 Coimbra, Portugal
}

Received 9 February 2006; received in revised form 13 June 2006; accepted 23 June 2006

Available online 28 June 2006

\begin{abstract}
The effects of tetrandrine (6,6', 7,12-tetramethoxy-2, 2'-dimethyl-berbaman) on the mitochondrial function were assessed on oxidative stress, mitochondrial permeability transition (MPT), and bioenergetics of rat liver mitochondria. At concentrations lower than 100 nmol/ mg protein, tetrandrine decreased the hydrogen peroxide formation, the extent of lipid peroxidation, the susceptibility to $\mathrm{Ca}^{2+}$-induced opening of MPT pore, and inhibited the inner membrane anion channel activity, not significantly affecting the mitochondrial bioenergetics. High tetrandrine concentrations (100-300 nmol/mg protein) stimulated succinate-dependent state 4 respiration, while some inhibition was observed for state 3 and $p$-trifluoromethoxyphenylhydrazone-uncoupled respirations. The respiratory control ratio and the transmembrane potential were depressed but the adenosine diphosphate to oxygen (ADP/O) ratio was less affected. A slight increase of the inner mitochondrial membrane permeability to $\mathrm{H}^{+}$and $\mathrm{K}^{+}$by tetrandrine was also observed. It was concluded that low concentrations of tetrandrine afford protection against liver mitochondria injury promoted by oxidative-stress events, such as hydrogen peroxide production, lipid peroxidation, and induction of MPT. Conversely, high tetrandrine concentrations revealed toxicological effects expressed by interference with mitochondrial bioenergetics, as a consequence of some inner membrane permeability to $\mathrm{H}^{+}$and $\mathrm{K}^{+}$ and inhibition of the electron flux in the respiratory chain. The direct immediate protective role of tetrandrine against mitochondrial oxidative stress may be relevant to clarify the mechanisms responsible for its multiple pharmacological actions.
\end{abstract}

(C) 2006 Elsevier B.V. and Mitochondria Research Society. All rights reserved.

Keywords: Bisbenzylisoquinoline alkaloide; Cancer; Mitochondrial bioenergetics; Permeability transition pore; Tetrandrine

\section{Introduction}

Mitochondria, whose main function is ATP synthesis by oxidative phosphorylation, have many other roles including the modulation of intracellular $\mathrm{Ca}^{2+}$ concentration and the regulation of apoptotic cell death (Lee and Wei, 2000; Murphy and Smith, 2000; Pedersen, 2000). Mitochondria are also considered to be, under normal and pathological conditions, the major endogenous source of reactive oxygen species (ROS), and perhaps of oxidative stress in general (Lee and Wei, 2000; Murphy and Smith, 2000; Pedersen, 2000).

\footnotetext{
${ }^{*}$ Corresponding author. Tel.: +351 239 855760; fax: +351 239855789.

E-mail address: mfer@ci.uc.pt (M.A.S. Fernandes).
}

Oxidative damage to mitochondria leads to a decline in the efficiency of oxidative phosphorylation and, in conditions of $\mathrm{Ca}^{2+}$ loading, it induces mitochondrial permeability transition (MPT), release of cytochrome $c$ and other factors able to trigger apoptosis (Kowaltowski and Vercesi, 1999; Kowaltowski et al., 2001).

Tetrandrine $\left(6,6^{\prime}\right.$, 7,12-tetramethoxy-2, 2'-dimethylberbaman), a bisbenzylisoquinoline alkaloide (Fig. 1) isolated from the dried root of the Chinese herb Stephania tetrandra (S. Moore), has been used as an effective anti-hypertensive and anti-arrhythmic agent in modern China (Wang et al., 2004). Tetrandrine blocks voltage-gated $\mathrm{Ca}^{2+}$ channels, large-conductance $\mathrm{Ca}^{2+}$-activated $\mathrm{K}^{+}$ (BK) channels, and intracellular $\mathrm{Ca}^{2+}$ pumps (Wang 


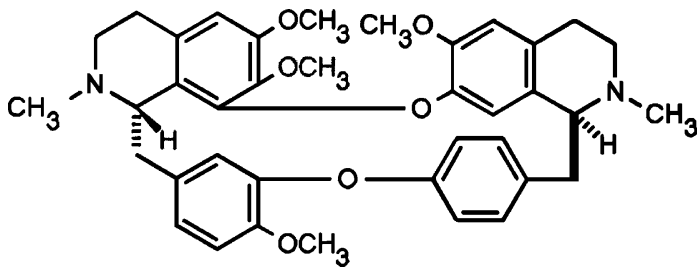

Fig. 1. Molecular structure of tetrandrine.

et al., 2004). Tetrandrine also exhibits anti-inflammatory and anti-tumour activities (Wang et al., 2004), and many studies support the contention that tetrandrine has pharmacological potential in cancer therapy (Yu-Jen, 2002). The beneficial effects of tetrandrine include induction of apoptosis in tumor cells, reversal of multidrug resistance to other anti-cancer drugs, sensitization of tumor cells to radiation, reduction of radiation injury in normal mononuclear cells and skin, and inhibition of angiogenesis (Yu-Jen, 2002). Recent studies have shown that tetrandrine-induced apoptosis in Neuro 2a mouse neuroblastoma cells, rat glioma cells (C-6) (Jin et al., 2002), human hepatoblastoma (Hep G2) (Oh and Lee, 2003), human leukaemia cells (U937) (Jang et al., 2004), and rat primary hepatocytes (Yan et al., 2006) is associated with ROS generation and cytochrome c release, thus suggesting that mitochondria are primarily involved. However, these studies seem to be controversial with those published by others (Seow et al., 1988; Matsuno et al., 1990; Castranova, 1994; Hui et al., 1996; Shen et al., 1999a,b, 2001; Koh et al., 2003; Sekiya et al., 2005; Ren et al., 1995; Liu et al., 2004) demonstrating that tetrandrine protects several types of cells from oxidative stress by acting as a ROS scavenger.

The purpose of this study was to investigate the direct immediate influence of tetrandrine on mitochondrial bioenergetics, oxidative stress, and permeability transition in an attempt to define its protective and toxicological effects as related to its action on mitochondria. We used rat liver mitochondria as a common biological material used in our laboratory to investigate general effects of compounds, specially on the mitochondrial function, as this is a wellcharacterized sub-cellular fraction with a high degree of purity $(90 \%)$ and easily obtained in large amounts $(150$ $200 \mathrm{mg}$ of protein per liver). Tetrandrine concentrations used in this study, expressed as nanomol tetrandrine per milligram mitochondrial protein and corresponding to a maximum of $80 \mu \mathrm{M}$ for protective actions, are within the concentration range used by other authors for studies with tissues and cells (Cao, 1996; Ye et al., 2000; Koh et al., 2003; Sekiya et al., 2005).

\section{Materials and methods}

\subsection{Animals}

Male Wistar rats $(250-350 \mathrm{~g})$, housed at $22 \pm 2{ }^{\circ} \mathrm{C}$ under artificial light for 12-h light/dark cycle and with access to water and food ad libitum, were used throughout the experiments. The experiments reported here were carried out in accordance with the National Requirements for Vertebrate Animal Research and in accordance with the European Convention for the Protection of Animals used for Experimental and other Scientific Purposes.

\subsection{Isolation of rat liver mitochondria}

Rat liver mitochondria were isolated from male Wistar rats ( 6 weeks) by differential centrifugation according to conventional methods (Gazotti et al., 1979). After washing, the pellet was gently resuspended in the washing medium at a protein concentration of about $50 \mathrm{mg} / \mathrm{ml}$. Protein content was determined by the biuret method (Gornall et al., 1949), using bovine serum albumin as a standard.

\subsection{Hydrogen peroxide generation}

Hydrogen peroxide $\left(\mathrm{H}_{2} \mathrm{O}_{2}\right)$ generation was measured fluorimetrically using a modification of the method previously described (Barja, 2002). In brief, mitochondria $(0.375 \mathrm{mg})$ were incubated at $30^{\circ} \mathrm{C}$ in $1.5 \mathrm{ml}$ of phosphate buffer, pH 7.4, containing $0.1 \mathrm{mM}$ EGTA, $145 \mathrm{mM} \mathrm{KCl}$, $30 \mathrm{mM}$ Hepes, $0.1 \mathrm{mM}$ homovalinic acid, and $6 \mathrm{U} / \mathrm{ml}$ horseradish peroxidase. The reactions were started by adding succinate $(10 \mathrm{mM})$ and stopped at $15 \mathrm{~min}$ with $0.5 \mathrm{ml}$ of cold $2 \mathrm{M}$ glycine- $\mathrm{NaOH}$ (pH 12) containing $25 \mathrm{mM}$ EDTA. The mitochondrial suspensions were centrifuged at $850 \mathrm{~g}$ for $10 \mathrm{~min}$. The fluorescence of supernatants was measured at $312 \mathrm{~nm}$ as excitation and $420 \mathrm{~nm}$ as emission wavelengths. The peroxide generation was calculated using a standard curve of $\mathrm{H}_{2} \mathrm{O}_{2}$. The standards and samples were incubated under the same conditions.

\subsection{Lipid peroxidation}

The extent of lipid peroxidation was evaluated by oxygen consumption using a Clark-type electrode, in a closed glass chamber equipped with magnetic stirring, thermostated at $30^{\circ} \mathrm{C}$. Mitochondria $(1.5 \mathrm{mg})$ were pre-incubated for $3 \mathrm{~min}$ in $1.5 \mathrm{ml}$ of a medium containing $175 \mathrm{mM} \mathrm{KCl}$, $10 \mathrm{mM}$ Tris- $\mathrm{Cl}$ (pH 7.4), supplemented with $3 \mu \mathrm{M}$ rotenone (in the presence or absence of tetrandrine) to avoid mitochondrial respiration induced by endogenous respiratory substrates. Iron solution was prepared immediately before use and protected from light. The changes in $\mathrm{O}_{2}$ tension were recorded in a potentiometric chart record and oxygen consumption calculated assuming an oxygen concentration of $232 \mathrm{nmol} \mathrm{O}_{2} / \mathrm{ml}$. Membrane lipid peroxidation was initiated by adding $1 \mathrm{mM}$ adenosine diphosphate (ADP)/0.1 mM Fe $\mathrm{Fe}^{2+}$ as oxidizing agents. Controls, in the absence of $\mathrm{ADP} / \mathrm{Fe}^{2+}$, were performed under the same conditions.

Lipid peroxidation was also determined by measuring thiobarbituric acid reactive substances (TBARS), using the thiobarbituric acid assay (Ernster and Nordenbrand, 1967). Aliquots of mitochondrial suspensions ( $0.5 \mathrm{ml} \mathrm{each}$ ), 
removed 10 min after the addition of $\mathrm{ADP} / \mathrm{Fe}^{2+}$, were added to $0.5 \mathrm{ml}$ of ice-cold $40 \%$ trichloroacetic acid. Then, $2 \mathrm{ml}$ of $0.67 \%$ of aqueous thiobarbituric acid containing $0.01 \%$ of 2,6-di-tert-butyl-p-cresol was added. The mixtures were heated at $90{ }^{\circ} \mathrm{C}$ for $15 \mathrm{~min}$, then cooled in ice for $10 \mathrm{~min}$, and centrifuged at $850 \mathrm{~g}$ for $10 \mathrm{~min}$. The supernatant fractions were collected and lipid peroxidation was estimated spectrophotometrically at $530 \mathrm{~nm}$. The amount of TBARS formed was calculated using a molar extinction coefficient of $1.56 \times 10^{5} / \mathrm{mol} / \mathrm{cm}$ and expressed as nmol TBARS $/ \mathrm{mg}$ protein (Buege and Aust, 1978).

\subsection{Extramitochondrial calcium movements}

Extramitochondrial-free $\mathrm{Ca}^{2+}$ was measured with the hexapotassium salt of the fluorescence calcium, sensitive probe Calcium Green 5-N (Rajdev and Reynolds, 1993). Mitochondria $(0.25 \mathrm{mg})$ were suspended in $2 \mathrm{ml}$ of buffer containing $200 \mathrm{mM}$ sucrose, $10 \mathrm{mM}$ Hepes-Tris $(\mathrm{pH}$ 7.4), $1 \mathrm{mM} \mathrm{KK_{2 }} \mathrm{PO}_{4}$ and $10 \mu \mathrm{M}$ EGTA, $2 \mu \mathrm{M}$ rotenone, $1 \mu \mathrm{g}$ oligomycin, and $80 \mathrm{nmol} \mathrm{Ca} \mathrm{Ca}^{2+} / \mathrm{mg}$ protein. Free $\mathrm{Ca}^{2+}$ was monitored with $100 \mathrm{nM}$ Calcium Green 5N. Fluorescence was continuously recorded in a water-jacked cuvette holder at $30^{\circ} \mathrm{C}$, using a PerkinElmer LS-50B fluorescence spectrometer with excitation and emission wavelengths of 506 and $531 \mathrm{~nm}$, respectively. Calcium uptake by mitochondria was initiated by addition of $5 \mathrm{mM}$ succinate. The minimum fluorescence of mitochondrial suspensions, after succinate addition, corresponds to maximum calcium uptake by mitochondria.

\subsection{Measurement of respiratory activities}

Oxygen consumption was monitored polarographically with a Clark-type electrode, in a closed glass chamber equipped with magnetic stirring, thermostated at $30^{\circ} \mathrm{C}$. Mitochondria (1.5 mg protein) were incubated in $1.5 \mathrm{ml}$ of medium containing $250 \mathrm{mM}$ sucrose, $10 \mathrm{mM}$ Hepes (pH 7.2), $20 \mathrm{mM} \mathrm{KCl}, 5 \mathrm{mM} \mathrm{K}_{2} \mathrm{HPO}_{4}$, and $2 \mathrm{mM} \mathrm{MgCl}_{2}$, supplemented with $2 \mu \mathrm{M}$ rotenone (in the presence and absence of tetrandrine), for $3 \mathrm{~min}$ before energization with $10 \mathrm{mM}$ succinate. To induce state 3 respiration, ADP $(100 \mu \mathrm{M})$ was added. Uncoupled respiration was initiated by the addition of $1 \mu \mathrm{M} p$-trifluoromethoxyphenylhydrazone (FCCP). $\mathrm{O}_{2}$ consumption was calculated considering that the saturation oxygen concentration was $232 \mathrm{nmol}$ $\mathrm{O}_{2} / \mathrm{ml}$. Control values are expressed in $\mathrm{nmol} \mathrm{O}_{2} / \mathrm{mg}$ protein/min. The respiratory control ratio (RCR) and ADP to oxygen ratio $(\mathrm{ADP} / \mathrm{O})$ were calculated according with a previously described method (Chance and Williams, 1956).

\subsection{Measurement of mitochondrial transmembrane potential}

The mitochondrial transmembrane potential $(\Delta \Psi)$ was measured indirectly based on the activity of the lipophilic cation tetraphenylphosphonium $\left(\mathrm{TPP}^{+}\right)$using a $\mathrm{TPP}^{+}$selective electrode, as previously described (Kamo et al., 1979). Mitochondria (1.5 mg protein) were incubated for $3 \mathrm{~min}$ in $1.5 \mathrm{ml}$ of medium containing $250 \mathrm{mM}$ sucrose, $10 \mathrm{mM}$ Hepes (pH 7.2), $20 \mathrm{mM} \mathrm{KCl}, 5 \mathrm{mM} \mathrm{K}_{2} \mathrm{HPO}_{4}$, and $2 \mathrm{mM} \mathrm{MgCl}$, supplemented with $2 \mu \mathrm{M}$ rotenone and $3 \mu \mathrm{M} \mathrm{TPP}^{+}$, at $30^{\circ} \mathrm{C}$, before energization with $10 \mathrm{mM}$ succinate. No correction was made for the "passive" binding of $\mathrm{TPP}^{+}$to the mitochondria membranes because the purpose of the experiments was to show relative changes in potential rather than absolute values. As a consequence, we can anticipate some overestimation for the $\Delta \Psi$ values. Tetrandrine did not affect $\mathrm{TPP}^{+}$binding to mitochondria membranes or the electrode response.

\subsection{Mitochondrial swelling}

Mitochondrial osmotic volume changes were measured by the apparent absorbance changes at $520 \mathrm{~nm}$ with a suitable spectrophotometer-recorder set up. Mitochondrial swelling methods were used to detect $\mathrm{H}^{+}$and $\mathrm{K}^{+}$mitochondrial inner membrane permeabilization (Vicente et al., 1998), activity of mitochondrial inner membrane anion channel (IMAC) (Beavis et al., 1985), and $\mathrm{Ca}^{2+}$-induced MPT (Costantini et al., 1996). The reactions were carried out at $30^{\circ} \mathrm{C}$, with $1 \mathrm{mg}$ mitochondrial protein in $2.5 \mathrm{ml}$ of the required media, as described below.

Mitochondrial inner membrane permeabilization to $\mathrm{H}^{+}$was detected in $\mathrm{K}$-acetate medium $[135 \mathrm{mM} \mathrm{K}$-acetate, $5 \mathrm{mM}$ Hepes (pH 7.1), $0.1 \mathrm{mM}$ EGTA, and $0.2 \mathrm{mM}$ EDTA] supplemented with $2 \mu \mathrm{M}$ rotenone. All assays were performed in the presence of $1 \mu \mathrm{g} / \mathrm{ml}$ valinomycin to permeabilize to $\mathrm{K}^{+}$. A control assay was performed in the presence of $1 \mu \mathrm{M}$ FCCP for total permeabilization to $\mathrm{H}^{+}$. Other assays were performed in the presence of tetrandrine instead of FCCP.

To detect $\mathrm{K}^{+}$mitochondrial inner membrane permeabilization, we used K-nitrate medium $\left[135 \mathrm{mM} \mathrm{KNO}_{3}, 5 \mathrm{mM}\right.$ Hepes (pH 7.1), 0.1 mM EGTA, and $0.2 \mathrm{mM}$ EDTA] supplemented with $2 \mu \mathrm{M}$ rotenone. Some assays were performed in the presence of $1 \mu \mathrm{g} / \mathrm{ml}$ valinomycin for total permeabilization to $\mathrm{K}^{+}$. Other assays were performed in the presence of tetrandrine instead of valinomycin.

Detection of IMAC activity used $\mathrm{KCl}$ medium $[135 \mathrm{mM}$ $\mathrm{KCl}, 5 \mathrm{mM}$ Hepes (pH 7.4), $0.1 \mathrm{mM}$ EGTA, and $0.2 \mathrm{mM}$ EDTA] supplemented with $2 \mu \mathrm{M}$ rotenone. Assays were performed in the presence of nigericin $(1 \mathrm{nmol} / \mathrm{mg}$ protein $)$, A23187 (10 nmol/mg protein), and valinomycin $(1 \mu \mathrm{g} / \mathrm{ml})$, in the absence or presence of tetrandrine. Control assays, in the absence of valinomycin or tetrandrine, were also performed. The $\mathrm{IC}_{50}$ value, concentration causing $50 \%$ of maximal inhibition for IMAC, was determined considering initial rates of swelling, as previously described (Zernig et al., 1990).

To detect $\mathrm{Ca}^{2+}$-induced MPT, we used a medium containing $200 \mathrm{mM}$ sucrose, $10 \mathrm{mM}$ Hepes-Tris ( $\mathrm{pH} 7.4)$, $1 \mathrm{mM} \mathrm{KH}_{2} \mathrm{PO}_{4}, 10 \mu \mathrm{M}$ EGTA, $2 \mu \mathrm{M}$ rotenone, and 
$1 \mu \mathrm{g} / \mathrm{ml}$ of oligomycin, in the absence and presence of tetrandrine. Mitochondria were energized with $5 \mathrm{mM}$ succinate and $80 \mathrm{nmol} \mathrm{Ca}{ }^{2+} / \mathrm{mg}$ protein was added to induce MPT. Control assays in the absence of $\mathrm{Ca}^{2+}$, and in presence of $\mathrm{Ca}^{2+}$ plus $1 \mu \mathrm{M}$ cyclosporin $\mathrm{A}$ (CsA) were also performed.

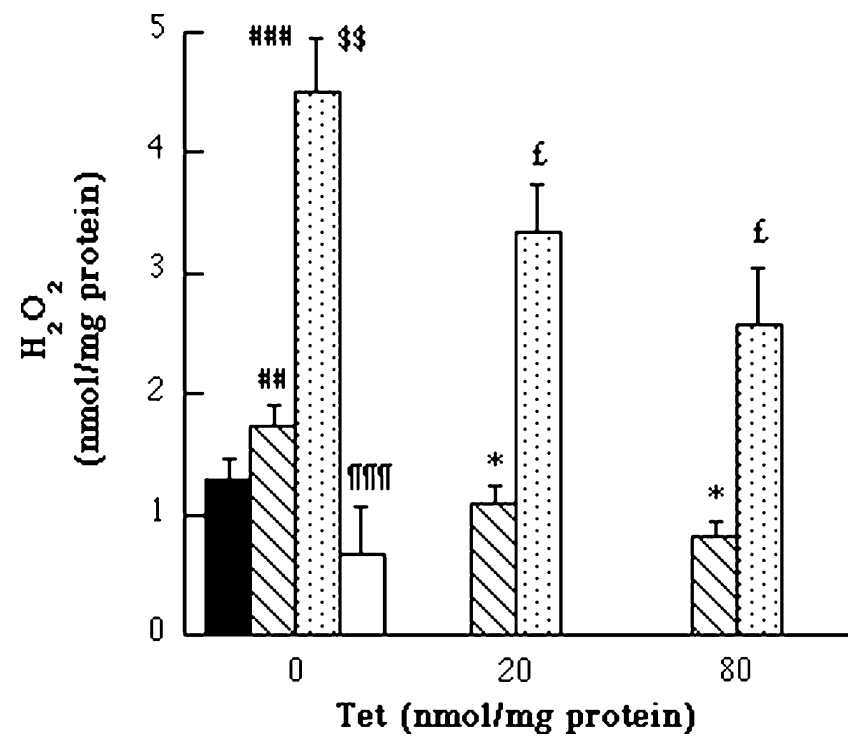

Fig. 2. Effect of tetrandrine on hydrogen peroxide production by rat liver mitochondria. Mitochondria were incubated under standard conditions as described in Section 2. The results correspond to the mean \pm SEM of four experiments obtained from different mitochondrial preparations. $\# \# \# p 0.001$ and ${ }^{\# \#} p<0.01$, when compared with basal production of $\mathrm{H}_{2} \mathrm{O}_{2}$ [in the absence of succinate (black bar)]; ${ }^{\$ \$} p<0.01$, when compared with control conditions [with succinate (dashed bars)]; ${ }^{\top} \uparrow_{p}<0.001$, when compared with maximal production of $\mathrm{H}_{2} \mathrm{O}_{2}$ [in the presence of succinate plus $10 \mu \mathrm{M}$ antimycin A (dotted bars)]; ${ }^{*} p<0.05$ and ${ }^{f} p<0.05$, when compared with the respective controls [without tetrandrine (Tet)]. Assays in the presence of succinate plus $10 \mu \mathrm{M}$ antimycin A plus $643 \mathrm{U} / \mathrm{ml}$ catalase (white bar).

\subsection{Statistical analysis}

All the experiments were performed using four independent experiments with different mitochondrial preparations. The values are expressed as mean \pm SEM Means were compared using ANOVA. Statistical significance was set at $p<0.05$.

\subsection{Chemicals}

All chemicals were obtained from Sigma Chemical Company (St Louis, MO, USA) except for tetrandrine, which was purchased from Aldrich (Madrid, Spain). Tetrandrine was dissolved in absolute dimethyl formamide (DMF) and diluted with ethanol. Pure solutions of DMF and ethanol (when necessary) were added for controls at the highest volume used in tetrandrine solutions $[1 \%(\mathrm{v} / \mathrm{v})$ of the experiments final volume], having no effects on the measured activities.

\section{Results}

\subsection{Effects of tetrandrine on mitochondrial oxidative stress}

The effects of tetrandrine on ROS production and oxidative damage were assessed detecting $\mathrm{H}_{2} \mathrm{O}_{2}$ generated by mitochondria (Fig. 2) and mitochondrial membrane lipid peroxidation induced by the pro-oxidant pair $\mathrm{ADP} / \mathrm{Fe}^{2+}$ (Fig. 3), respectively. In the absence of tetrandrine, the $\mathrm{H}_{2} \mathrm{O}_{2}$ generated by succinate-respiring mitochondria significantly increased as compared with non-respiring mitochondria (Fig. 2). Treatment of mitochondria with antimycin $\mathrm{A}$, an inhibitor of complex III, maximally stimulated the $\mathrm{H}_{2} \mathrm{O}_{2}$ produced by succinate-respiring mitochondria. This effect was strongly reduced by catalase to levels (more than $80 \%$ inhibition) below those observed
A $\mathbf{A D P} / \mathrm{Fe}^{2+}$

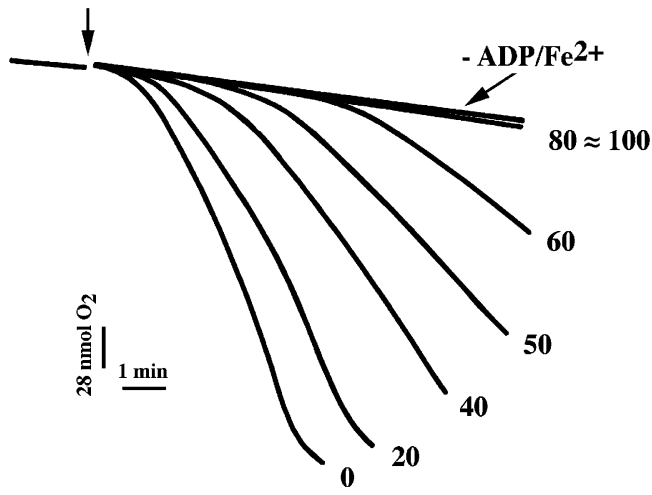

Tet (nmol/mg protein)
B

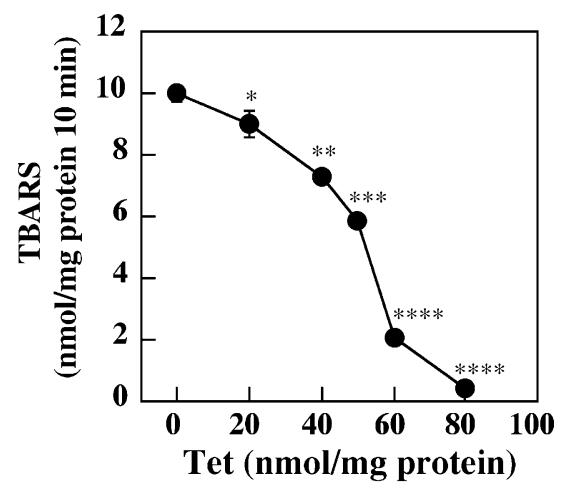

Fig. 3. Effect of tetrandrine on membrane lipid peroxidation of rat liver mitochondria induced by the pro-oxidant pair ADP/Fe ${ }^{2+}$. Lipid peroxidation was evaluated by oxygen consumption (A) and TBARS assay (B). The traces in (A) represent typical direct recordings representative of four experiments obtained from different mitochondrial preparations; $-\mathrm{ADP} / \mathrm{Fe}^{2+}$, controls in the absence of $\mathrm{ADP} / \mathrm{Fe}^{2+}$. The data in (B) correspond to the mean $\pm \mathrm{SEM}$ of four independent experiments. ${ }^{*} p<0.05 ;{ }^{* *} p<0.01 ;{ }^{* *} p<0.001 ;{ }^{* * *} p<0.0001$ as compared with mitochondria submitted to ADP/Fe ${ }^{2+}$ treatment without tetrandrine. 
in basal conditions (mitochondria in the absence of succinate), considering this as $\mathrm{H}_{2} \mathrm{O}_{2}$ assay control. Tetrandrine concentrations up to $80 \mathrm{nmol} / \mathrm{mg}$ protein significantly reduced $\mathrm{H}_{2} \mathrm{O}_{2}$ generation by succinate-respiring mitochondria either in the absence or presence of antimycin A. A maximal decrease of $\mathrm{H}_{2} \mathrm{O}_{2}$ generation (of about $50 \%$ ) was observed at $80 \mathrm{nmol}$ tetrandrine/mg protein for both conditions.

Fig. 3 shows the effect of tetrandrine on lipid peroxidation of rat liver mitochondria. This effect was evaluated by measuring oxygen consumption (Fig. 3A) and TBARS formation (Fig. 3B) due to membrane peroxidation induced by the pro-oxidant pair ADP/ $/ \mathrm{Fe}^{2+}$. In the absence of tetrandrine and after the addition of the pro-oxidant pair, it is possible to distinguish a two-phase kinetics in oxygen consumption: an initial lag phase, slow oxygen consumption, lasting about $1 \mathrm{~min}$, is followed by a rapid oxygen consumption phase. The lag phase is probably related with the time required for the generation of a sufficient amount of the perferryl ion complex (ADP- $\mathrm{Fe}^{2+}-\mathrm{O}_{2} \leftrightarrow \mathrm{ADP}-$ $\mathrm{Fe}^{3+}-\mathrm{O}_{2}^{-}$) which has been suggested to be responsible for the initiation of lipid peroxidation. The rapid oxygen consumption phase is probably due to the oxidation of the polyunsaturated fatty acid acyl chain of membrane phospholipids by ROS and, consequently, to the propagation phase of lipid peroxidation (Sassa et al., 1990). Tetrandrine concentrations up to $100 \mathrm{nmol} / \mathrm{mg}$ protein enlarge the lag phase of slow oxygen consumption before oxygen uptake burst induced by the complex ADP $/ \mathrm{Fe}^{2+}$, and decrease the consequent rate of the rapid oxygen consumption phase (Fig. 3A). This suggests that tetrandrine inhibits both the initiation and the propagation of lipid peroxidation of mitochondrial membranes with total inhibition of lipid peroxidation at $80 \mathrm{nmol} / \mathrm{mg}$ protein. These results agree with the quantitative evaluation of TBARS formationperformed to confirm the clear protective effect of tetrandrine observed by oxygen consumption. Fig. 3B shows that the kinetics of TBARS formation induced by $\mathrm{ADP} / \mathrm{Fe}^{2+}$ is similar to that observed for oxygen consumption. The same range of tetrandrine concentrations used to inhibit oxygen consumption inhibited TBARS formation. TBARS formation in the absence of $\mathrm{ADP} / \mathrm{Fe}^{2+}$ is negligible (results not shown).

\subsection{Effect of tetrandrine on $\mathrm{Ca}^{2+}$-induced MPT}

The effect of tetrandrine on $\mathrm{Ca}^{2+}$-induced MPT was evaluated by passive osmotic swelling (Fig. 4A), $\Delta \Psi$ dissipation (Fig. 4B), and $\mathrm{Ca}^{2+}$ release (Fig. 4C). It is shown, in Fig. 4A, that swelling occurs in $\mathrm{Ca}^{2+}$-loaded, succinate-energized rat liver mitochondria. CsA, a known MPT inhibitor (Broekemeier et al., 1989), totally blocks this effect, showing that swelling has been induced by MPT. Treatment of mitochondria with tetrandrine concentrations up to $20 \mathrm{nmol} / \mathrm{mg}$ protein, prior to adding succinate and $\mathrm{Ca}^{2+}$, enlarged the lag time required for mitochondria to induce $\mathrm{Ca}^{2+}$-dependent MPT. With the $\mathrm{TPP}^{+}$-electrode,
A
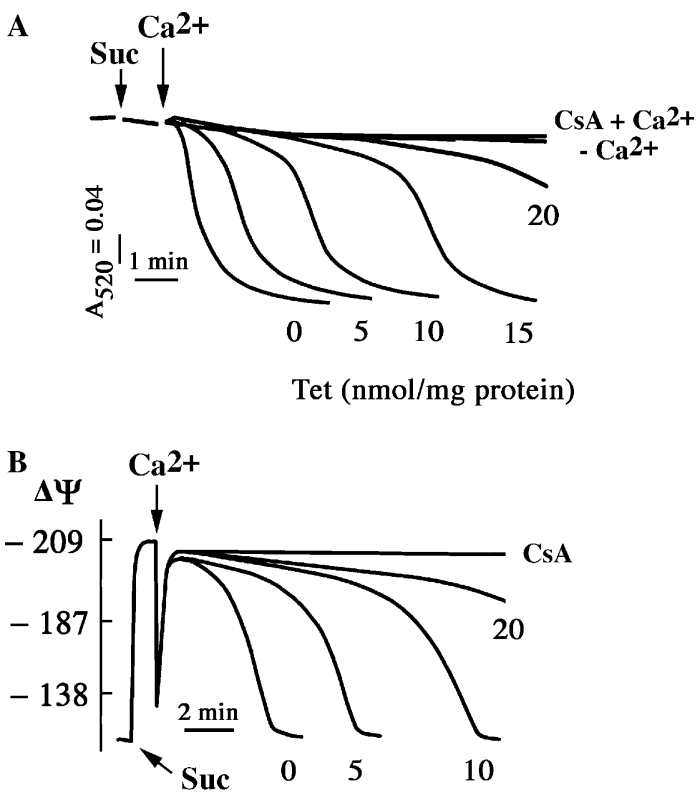

Tet (nmol/mg protein)

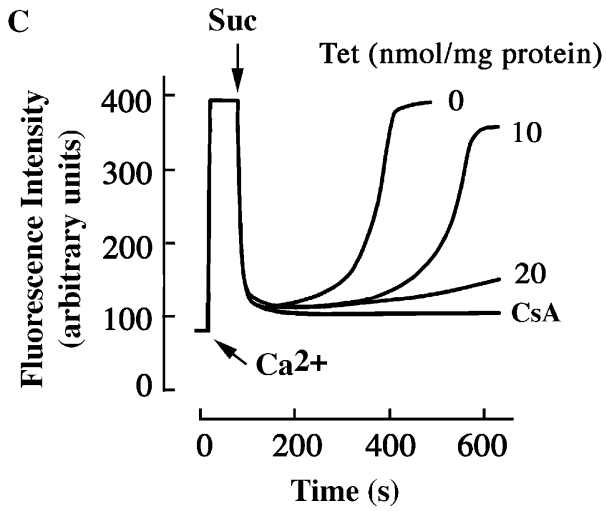

Fig. 4. Effect of tetrandrine on $\mathrm{Ca}^{2+}$-induced MPT. Assays of mitochondrial swelling (A), mitochondrial transmembrane potential $(\Delta \Psi)(\mathrm{B})$, and calcium fluxes (C), were obtained in a medium containing $200 \mathrm{mM}$

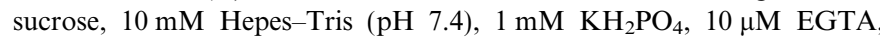
$2 \mu \mathrm{M}$ rotenone, and $1 \mu \mathrm{g} / \mathrm{ml}$ of oligomycin, and incubated for $3 \mathrm{~min}$ at $30{ }^{\circ} \mathrm{C}$. Mitochondria were energized with $5 \mathrm{mM}$ succinate (Suc) and $80 \mathrm{nmol} \mathrm{Ca}^{2+} / \mathrm{mg}$ protein $\left(\mathrm{Ca}^{2+}\right)$ were added where indicated to induce MPT. $1 \mu \mathrm{M}$ cyclosporin A (CsA) was used to confirm MPT induction. Assays were performed as described in Section 2. The traces are typical recordings representative of four experiments obtained from different mitochondrial preparations.

this inhibitory effect of tetrandrine was also investigated on $\mathrm{Ca}^{2+}$-induced dissipation of $\Delta \Psi$ associated with MPT induction (Fig. 4B). In the absence of tetrandrine, addition of $\mathrm{Ca}^{2+}$ ( $80 \mathrm{nmol} / \mathrm{mg}$ protein) to succinate-energized mitochondria caused a transient depolarization followed by fast repolarization, after $\mathrm{Ca}^{2+}$ accumulation. This repolarization is sustained for a short lag time before irreversible $\Delta \Psi$ dissipation. Similarly to CsA, tetrandrine concentrations up to $20 \mathrm{nmol} / \mathrm{mg}$ protein, prior to succinate addition and $\mathrm{Ca}^{2+}$, enlarged the lag time required for $\mathrm{Ca}^{2+}$-induced irreversible depolarization of $\Delta \Psi$. This means that, in the presence of tetrandrine, the $\mathrm{Ca}^{2+}$ uptake causes $\Delta \Psi$ dissi- 
pation but, after $\mathrm{Ca}^{2+}$ accumulation, mitochondria develop sustained $\Delta \Psi$, demonstrating the inhibitory effect of tetrandrine on $\mathrm{Ca}^{2+}$-induced MPT. Fluorescent calcium-sensitive probe Calcium Green 5-N (Fig. 4C), like TPP $^{+}$-electrode and swelling assays, also confirmed the results of inhibition of MPT induction by tetrandrine, reinforcing the conclusion that tetrandrine protects mitochondria from $\mathrm{Ca}^{2+}$-induced MPT, not affecting the ability of mitochondria to accumulate $\mathrm{Ca}^{2+}$.

\subsection{Effects of tetrandrine on the IMAC activity}

The effect of tetrandrine on IMAC activity was evaluated by passive osmotic swelling of non-respiring rat liver mitochondria suspended in $\mathrm{KCl}$ medium (Fig. 5). In the presence of the ionophore A23187, mitochondrial matrix $\mathrm{Mg}^{2+}$ is depleted in exchange for $\mathrm{H}^{+}$, strongly increasing $\mathrm{Cl}^{-}$permeability via IMAC. So, in the presence of valinomycin to permeabilize $\mathrm{K}^{+}$, plus nigericin to induce $\mathrm{K}^{+} / \mathrm{H}^{+}$ antiport, A23187 strongly stimulates swelling of non-respiring mitochondria suspended in $\mathrm{KCl}$ medium. This swelling is increasingly prevented by the presence of tetrandrine concentrations up to $62.5 \mathrm{nmol} / \mathrm{mg}$ protein, indicating that IMAC-dependent $\mathrm{Cl}^{-}$transport has been inhibited. The $\mathrm{IC}_{50}$ value for IMAC inhibition by tetrandrine was $12.5 \pm 2 \mathrm{nmol} / \mathrm{mg}$ protein.

\subsection{Effects of tetrandrine on mitochondrial bioenergetics}

The effects of tetrandrine on succinate-supported respiratory rates (state 4 , state 3 , and $\mathrm{FCCP}$-uncoupled respiration) and respiratory indices RCR and $\mathrm{ADP} / \mathrm{O}$ ratio of rat liver mitochondria are significant at concentrations higher

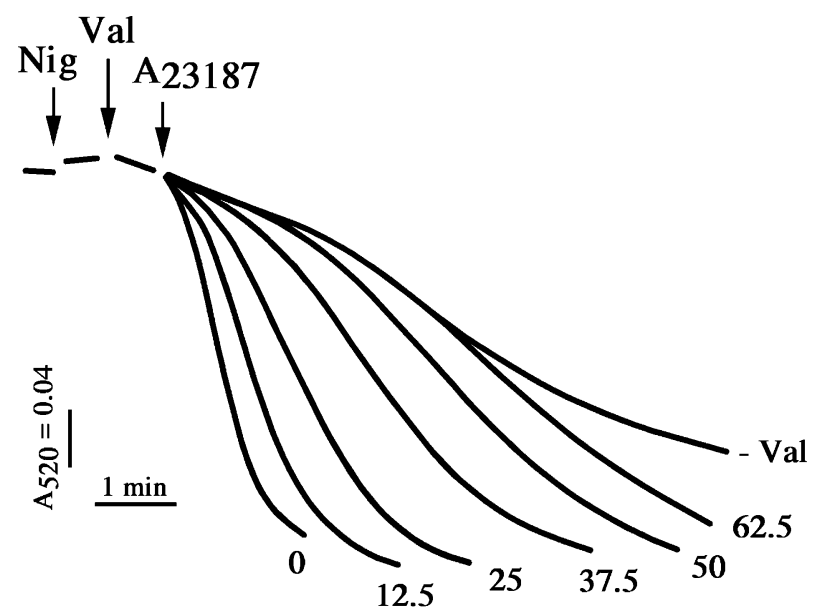

Tet (nmol/mg protein)

Fig. 5. Effect of tetrandrine on the mitochondrial inner membrane anion channel (IMAC). Assays were performed as described in Section 2, in the absence or presence of tetrandrine (Tet). Nig, $1 \mathrm{nmol} / \mathrm{mg}$ protein nigericin; Val, $1 \mathrm{nmol} / \mathrm{mg}$ protein valinomycin; A23187, $10 \mathrm{nmol} / \mathrm{mg}$ protein, $4 \mathrm{~min}$ after valinomycin; -Val, assay performed in the absence of valinomycin and tetrandrine. The traces are typical recordings representative of four experiments obtained from different mitochondrial preparations.

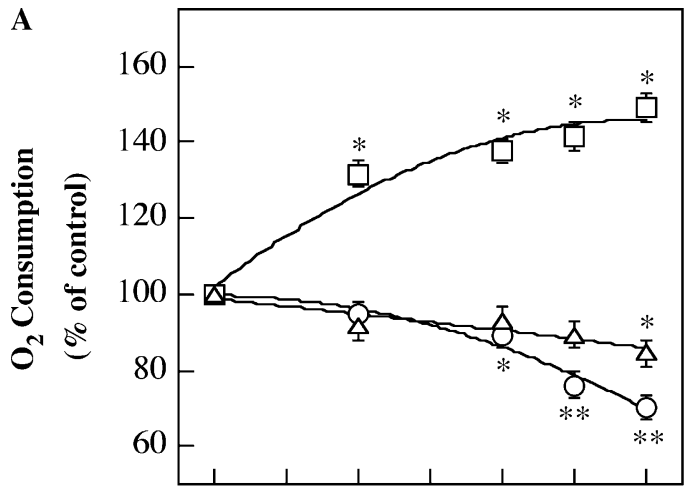

B

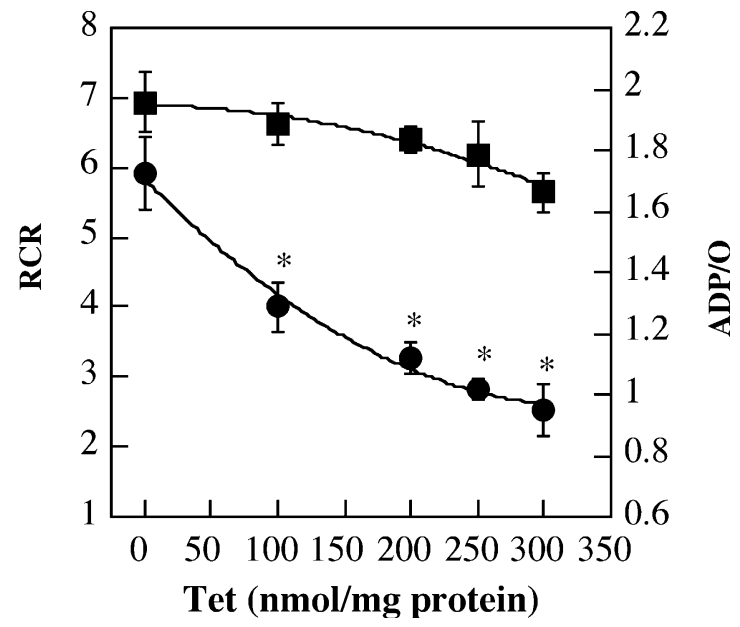

Fig. 6. Effect of tetrandrine on succinate-supported respiration of rat liver mitochondria. (A) $\mathrm{O}_{2}$ consumption in state 4 (open squares), state 3 (open circles), and uncoupled respiration (open triangles). (B) respiratory indices $\mathrm{RCR}$ (closed circles), and ADP/O (closed squares). Control values expressed in $\mathrm{nmol} \mathrm{O}_{2} / \mathrm{mg}$ protein. min: state $4=8.9 \pm 0.82$; state $3=55.06 \pm 0.45$; uncoupled respiration $=80.22 \pm 2.25$. The results correspond to the mean \pm SEM of four experiments obtained from different mitochondrial preparations. ${ }^{*} p<0.05 ;{ }^{* *} p<0.01$, when compared with the control (without tetrandrine).

than $100 \mathrm{nmol} / \mathrm{mg}$ protein. As observed in Fig. 6, state 4 respiration was maximally stimulated at $300 \mathrm{nmol} / \mathrm{mg}$ protein $(40 \%)$. At this concentration, state 3 respiration was depressed $(30 \%)$ at a higher level than uncoupled respiration $(15 \%)$ (Fig. 6A). Tetrandrine, at the concentration range up to $300 \mathrm{nmol} / \mathrm{mg}$ protein, significantly depressed RCR (from about 6 to less than 3), but the ADP/O ratio was only slightly decreased (from about 2 to 1.7) (Fig. 6B), suggesting a higher influence on the membrane permeability than on some specific oxidative phosphorylation intervener. These results are confirmed by Fig. 7, where tetrandrine dissipates $\Delta \Psi$ induced by succinate-dependent respiration, consequently decreasing oxidative phosphorylation efficiency.

As a putative mechanism to explain the results described above, mitochondrial inner membrane permeabilizations to $\mathrm{H}^{+}$and $\mathrm{K}^{+}$by tetrandrine were evaluated by swelling of non-respiring mitochondria suspended in potassium acetate and potassium nitrate media, respectively (Fig. 8). Protonated acetate can cross the mitochondrial inner 


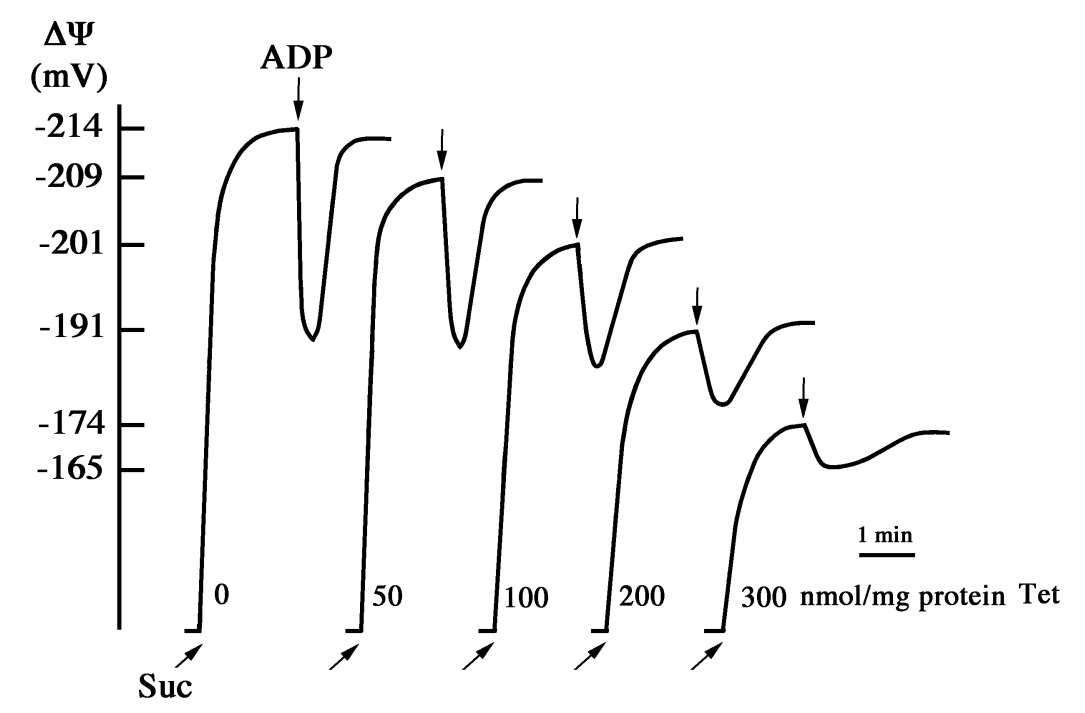

\begin{tabular}{ccccc}
\hline \multirow{2}{*}{$\begin{array}{c}\text { Tetrandrine } \\
\text { (nmol/mg protein) }\end{array}$} & $\begin{array}{c}\text { Succinate } \\
\text { energization }\end{array}$ & $\begin{array}{c}\text { ADP } \\
\text { depolarization }\end{array}$ & Repolarization & $\begin{array}{c}\text { Repolarization } \\
\text { Time (s) }\end{array}$ \\
\hline 0 & $214 \pm 1$ & $25 \pm 1.7$ & $213 \pm 1.3$ & $75 \pm 8.6$ \\
50 & $208 \pm 1.4^{*}$ & $23 \pm 2.5$ & $206 \pm 1.8^{*}$ & $90 \pm 5.2$ \\
100 & $203 \pm 1.6^{*}$ & $14 \pm 1.9$ & $202 \pm 1.2^{*}$ & $98 \pm 4.4$ \\
200 & $190 \pm 1.5^{*}$ & $10 \pm 2.1$ & $192 \pm 2.0^{*}$ & $110 \pm 5.0$ \\
300 & $177 \pm 2.1^{*}$ & $9 \pm 2.5^{*}$ & $177 \pm 2.8^{*}$ & $138 \pm 6.2^{*}$ \\
\hline
\end{tabular}

Fig. 7. Effect of tetrandrine on succinate-dependent transmembrane potential $(\Delta \Psi)$ and phosphorylation of rat liver mitochondria. ADP, addition of $100 \mathrm{nmol}$ ADP; Suc, $10 \mathrm{mM}$ succinate; Tet, tetrandrine. The traces are typical recordings representative of four experiments obtained from different mitochondrial preparations. The lower table shows the mean \pm SEM of membrane potential at the different indicated situations. ${ }^{*} p<0.05$, values statistically different from control (in the absence of tetrandrine).

membrane and then, in the mitochondrial matrix, dissociate to the acetate anion and $\mathrm{H}^{+}$, producing a proton gradient. A valinomycin-dependent swelling only occurs if the proton gradient is dissipated. Tetrandrine concentrations up to $300 \mathrm{nmol} / \mathrm{mg}$ protein lead to a low rate of valinomycin-dependent mitochondrial swelling, indicating small proton conductance action through the mitochondrial inner membrane $(15 \%$ of the maximum estimated with FCCP) (Fig. 8A). Mitochondrial inner membrane is permeable to nitrate $\left(\mathrm{NO}_{3}{ }^{-}\right)$, but optimal swelling in potassium nitrate medium $\left(\mathrm{KNO}_{3}\right)$ is observed only in conditions of $\mathrm{K}^{+}$permeabilization. Maximum rate of swelling is observed by adding valinomycin to provide $\mathrm{K}^{+}$entry. Addition of tetrandrine concentrations up to $300 \mathrm{nmol} / \mathrm{mg}$ protein, instead of valinomycin, only induced a small swelling rate $(17 \%)$, indicating that the $\mathrm{K}^{+}$conductance through the inner mitochondrial membrane was only slightly affected by the highest tested concentration of tetrandrine (Fig. 8B).

\section{Discussion}

Tetrandrine protects several types of cells from oxidative stress by acting as a ROS scavenger, namely neutrophils (Seow et al., 1988; Matsuno et al., 1990; Castranova, 1994; Hui et al., 1996; Shen et al., 1999a,b, 2001), cerebellar granule neurons (Koh et al., 2003), erythrocytes (Sekiya et al.,
2005), and tissues from heart (Ren et al., 1995) and liver (Liu et al., 2004). Tetrandrine was shown to induce depression of $\mathrm{H}_{2} \mathrm{O}_{2}$ production and inhibition of $\mathrm{O}_{2} \cdot{ }^{-}$radical generation (Seow et al., 1988), and also to efficiently react with $\mathrm{OH}^{-}$and to scavenge $\mathrm{O}_{2}{ }^{-}$radical (Shi et al., 1995; Cao, 1996; Ye et al., 2000). It has been demonstrated, using the Fenton reaction for $\mathrm{OH}$ production and xanthine/xanthine oxidase for $\mathrm{O}_{2}^{-}$production, that tetrandrine is an antioxidant comparable with ascorbate, glutathione, and cysteine (Cao, 1996; Ye et al., 2000). In quite agreement with these authors, we showed that, using liver mitochondrial fractions, tetrandrine directly protected from oxidative stress at concentrations not affecting oxidative phosphorylation.

Both depression of $\mathrm{H}_{2} \mathrm{O}_{2}$ (Fig. 2) and inhibition of membrane lipid peroxidation (Fig. 3) detected the protective effect of tetrandrine from mitochondrial oxidative stress. Depression of $\mathrm{H}_{2} \mathrm{O}_{2}$ production by tetrandrine can be a result of its ability to scavenge $\mathrm{O}_{2}{ }^{-}$, a ROS generated by the mitochondrial respiratory chain activity, which is then dismutated into $\mathrm{H}_{2} \mathrm{O}_{2}$ by the mitochondrial enzyme superoxide dismutase and/or it can be due to the ability of tetrandrine to induce mild uncoupling, resulting in slight $\Delta \Psi$ dissipation (Cadenas and Davies, 2000; Lenaz, 2001; Ricci et al., 2003; Cadenas, 2004; Brookes, 2005; Jezek and Hlavatá, 2005). Indeed, low concentrations of tetrandrine (50 and $100 \mathrm{nmol} / \mathrm{mg}$ protein) induce slight but 
A
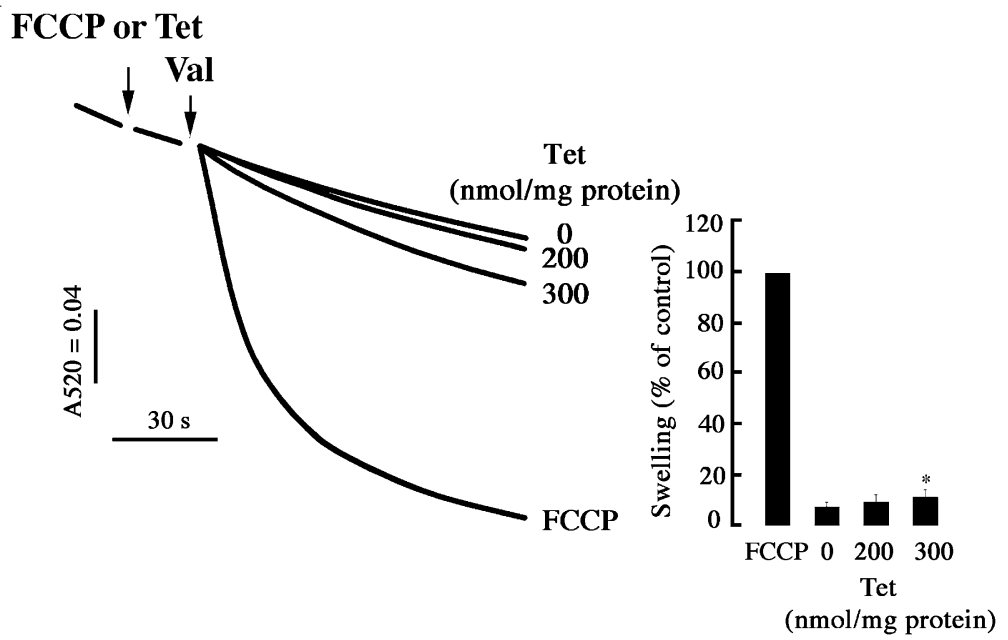

B

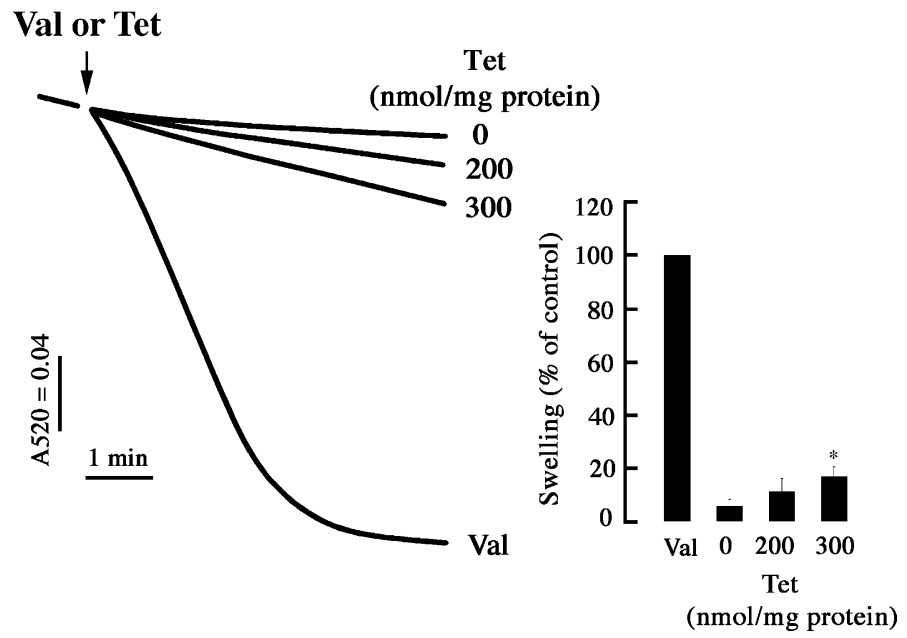

Fig. 8. Effect of tetrandrine on the permeabilization to $\mathrm{H}^{+}$and $\mathrm{K}^{+}$by inner membrane of rat liver mitochondria. Passive osmotic swelling of mitochondria suspended in $\mathrm{K}$-acetate (A) and $\mathrm{KNO}_{3}$ (B) media, respectively. Assays were performed as described in Section 2 . Where indicated by arrows, $1 \mu \mathrm{M}$ FCCP or tetrandrine (Tet) and $1 \mu \mathrm{g} / \mathrm{mL}$ valinomycin (Val) were added. The traces are typical recordings representative of four experiments obtained from different mitochondrial preparations. Insets: graphs showing the mean \pm SEM of mitochondrial swelling expressed as percentage of maximum swelling obtained with $1 \mu \mathrm{M} \mathrm{FCCP}$ or $1 \mu \mathrm{M}$ Val. ${ }^{*} p<0.05$, values statistically different from control (in the absence of tetrandrine).

significant dissipation of $\Delta \Psi$ (Fig. 7). The inhibitory action of tetrandrine on membrane lipid peroxidation can be a result of its ability to prevent ROS production derived from $\mathrm{ADP} / \mathrm{Fe}^{2+}$. In so doing, tetrandrine avoids formation of the perferryl ion complex, ADP- $-\mathrm{Fe}^{3+}-\mathrm{O}_{2}{ }^{-}$and, consequently, the oxidation of the polyunsaturated fatty acid acyl chain of membrane phospholipids, a mechanism suggested to be responsible for lipid peroxidation (Sassa et al., 1990).

IMAC is a non-selective anion channel that carries a wide variety of anions and it is regulated by $\mathrm{Mg}^{2+}$ and $\mathrm{H}^{+}$matrix concentrations (Beavis, 1992), and by oxidative stress (Aon et al., 2003). IMAC is believed to be involved in mitochondrial volume homeostasis (Beavis, 1992), in the efflux of the $\mathrm{O}_{2}{ }^{-}$anion from mitochondria during ischemia preconditioning (Vanden Hoek et al., 1998), and in synchronized oscillations of mitochondrial membrane potential from isolated cardiac myocytes (O'Rourke, 2000; Aon et al., 2003).

It has been demonstrated that IMAC blockers avoid $\mathrm{O}_{2}{ }^{-}$ efflux from respiring mitochondria, protecting cells from degradative effects of ROS (Aon et al., 2003). Low concentrations of tetrandrine, interfering with the $\mathrm{Cl}^{-}$movement across the mitochondrial membrane (Fig. 5), strongly inhibit $\operatorname{IMAC}\left(\mathrm{IC}_{50}=12.5 \pm 2 \mathrm{nmol} / \mathrm{mg}\right.$ protein $)$, indicating that the compound is a potent IMAC blocker. We suggest that tetrandrine, acting as IMAC blocker (Fig. 5) and also as $\mathrm{O}_{2}{ }^{-}$radical scavenger (Shi et al., 1995; Cao, 1996; Ye et al., 2000), can protect cells from oxidative stress. Furthermore, the interaction of tetrandrine with IMAC, admits interference with $\mathrm{Cl}^{-}$movements. Indeed, others showed that tetrandrine inhibited the $\mathrm{Ca}^{2+}$-activated $\mathrm{Cl}^{-}$channel (a volume-regulated $\mathrm{Cl}^{-}$channel) inhibiting cell proliferation in cultured human umbilical vein endothelial cells (Fang et al., 2004). This suggests that interaction of the compound with anion channels can be relevant for its pharmacological activity as an anti-cancer drug.

Confirming tetrandrine protective action from oxidative stress, we observed that very low concentrations $(\leqslant 20 \mathrm{nmol} / \mathrm{mg}$ protein) protected rat liver mitochondria 
against $\mathrm{Ca}^{2+}$-induced MPT, as revealed by different methods (Fig. 4). The ability of mitochondria to accumulate $\mathrm{Ca}^{2+}$ was not affected, showing no interference with $\mathrm{Ca}^{2+}$ transport. In fact, tetrandrine-induced repolarization and $\mathrm{Ca}^{2+}$ re-uptake by mitochondria after the onset of MPT (results not shown). This suggests that tetrandrine action, avoiding ROS production, inhibits induction of MPT, not interfering with $\mathrm{Ca}^{2+}$ uptake machinery. A critical factor for induction of MPT is the oxidation of protein thiol groups of the pore complex, creating diethyl cross-links (Costantini et al., 1996; Halestrap et al., 1997; McStay et al., 2002). As tetrandrine protects rat liver mitochondria from ROS production and membrane lipid peroxidation (Figs. 2 and 3), the most plausible hypothesis to explain MPT inhibition is concerned with the prevention of oxidative stress-induced thiol-bridge formation.

Concerning the discrepancy between our "in vitro" results, revealing protection of rat liver mitochondria against $\mathrm{Ca}^{2+}$-induced MPT, and the "ex vivo" results showing enhanced $\mathrm{Ca}^{2+}$-induced MPT in rat liver mitochondria of tetrandrine-treated rats (Yan et al., 2006), we can say that our results were confirmed using three different methods (swelling, $\mathrm{TPP}^{+}$-electrode, and Calcium Green 5$\mathrm{N}$ ), and MPT induction was confirmed by CsA. We also used a $\mathrm{Ca}^{2+} /$ protein ratio of $80 \mathrm{nmol} \mathrm{Ca}{ }^{2+} / 1 \mathrm{mg}$ protein. The results reported by others (Yan et al., 2006) only used mitochondrial swelling and a very different $\mathrm{Ca}^{2+} /$ protein ratio ( $75 \mathrm{nmol} \mathrm{Ca}{ }^{2+} / 75 \mu \mathrm{g}$ protein), not using CsA to clearly confirm mitochondrial swelling dependent on MPT induction. Thus, the high $\mathrm{Ca}^{2+}$ /protein ratio they used in the swelling assays (Yan et al., 2006) can putatively be due to mitochondrial membrane damage by $\mathrm{Ca}^{2+}$ toxicity rather than MPT induction.

Our results, using isolated rat liver mitochondria, showing tetrandrine protection from ROS and MPT induction, suggest that the compound may protect cells from oxidative stress-induced apoptosis, in quite agreement with other authors (Seow et al., 1988; Matsuno et al., 1990; Castranova, 1994; Ren et al., 1995; Hui et al., 1996; Shen et al., 1999a,b, 2001; Koh et al., 2003; Liu et al., 2004; Sekiya et al., 2005). However, others showed that tetrandrine-induced apoptosis associated with oxidative stress and MPT induction in both cancer cell lines (Jin et al., 2002; Oh and Lee, 2003; Jang et al., 2004) and rat primary hepatocytes (Yan et al., 2006). This discrepancy suggests that tetrandrine-induced apoptosis is due to factors other than a direct immediate interaction of tetrandrine with isolated mitochondria. The most plausible hypothesis is concerned with the possibility that, at the cellular level, apoptotic factors can be induced by some tetrandrine metabolite (Wu et al., 2004).

Tetrandrine concentrations higher than $100 \mathrm{nmol} / \mathrm{mg}$ mitochondrial protein interfere with mitochondrial bioenergetics inducing some stimulation of succinate-supported respiration in state 4 and some inhibition in state 3 . This is putatively a consequence of a small permeabilization of mitochondrial inner membrane to $\mathrm{H}^{+}$and $\mathrm{K}^{+}$(Fig. 6). This permeabilization, associated with slight inhibition of elec- tron flow in the respiratory chain, explains the extensive decrease of RCR simultaneous with a slight decrease of $\mathrm{ADP} / \mathrm{O}$. In fact, oxidative phosphorylation efficiency is insensitive to small specific permeabilization to protons, responsible for a considerable decrease of RCR (Fig. 6B), a fact that can be demonstrated by adding very low concentrations of a protonophore, such as dinitrophenol (results not shown). These results obtained with high concentrations of tetrandrine show that, considering its broad toxicological effects, this concentration range must be avoided to attain its pharmacological actions.

In conclusion, it should be emphasized that our studies analyze a direct immediate action of tetrandrine on mitochondrial mechanisms. Low concentrations of tetrandrine (100 nmol/mg protein) afford protection against liver mitochondrial injury promoted by oxidative stress events, such as ROS production, lipid peroxidation, and $\mathrm{Ca}^{2+}$-induced MPT. These results may be relevant to its multiple pharmacological actions. Toxicological effects of tetrandrine on the direct mitochondrial metabolism only occur at high concentrations ( $>100 \mathrm{nmol} / \mathrm{mg}$ protein), acting to permeabilize membranes to $\mathrm{H}^{+}$and $\mathrm{K}^{+}$, and to inhibit mitochondrial electron transfer in the respiratory chain.

\section{Acknowledgements}

This study was supported by Portuguese Research Council (FCT), Portugal, Environment and Life Science Institute (IAV), Institute of Marine Research (IMAR), and Center for Neuroscience and Cell Biology (CNC) of the University of Coimbra, Portugal.

\section{References}

Aon, M.A., Cortassa, S., Marbán, E., O’Rourke, B., 2003. Synchronized whole cell oscillations in mitochondrial metabolism triggered by a local release of reactive oxygen species in cardiac myocytes. J. Biol. Chem. 278, 44735-44744.

Barja, G., 2002. The quantitative measurement of $\mathrm{H}_{2} \mathrm{O}_{2}$ generation in isolated mitochondria. J. Bioenerg. Biomembr. 34, 227-233.

Beavis, A.D., 1992. Properties of the inner membrane anion channel in intact mitochondria. J. Bioenerg. Biomembr. 24, 77-90.

Beavis, A.D., Brannan, R.D., Garlid, K.D., 1985. Swelling and contraction of the mitochondrial matrix. I. Structural interpretation of the relationship between light scattering and matrix volume. J. Biol. Chem. 260, 13424-13433.

Broekemeier, K.M., Dempsey, M.E., Pfeiffer, D.R., 1989. Cyclosporin A is a potent inhibitor of the inner membrane permeability transition in liver mitochondria. J. Biol. Chem. 264, 7826-7830.

Brookes, P.S., 2005. Mitochondrial $\mathrm{H}^{+}$leak and ROS generation: an odd couple. Free Radic. Biol. Med. 38, 12-23.

Buege, J.A., Aust, S.D., 1978. Microsomal lipid peroxidation. Methods Enzymol. 52, 302-310.

Cadenas, E., 2004. Mitochondrial free radical production and cell signalling. Mol. Aspects Med. 25, 17-26.

Cadenas, E., Davies, K.J., 2000. Mitochondrial free radical generation, oxidative stress, and ageing. Free Radic. Biol. Med. 29, 222-230.

Cao, Z.F., 1996. Scavenging effect of tetrandrine of active oxygen radicals. Planta Med. 62, 413-414.

Castranova, V., 1994. Generation of oxygen radicals and mechanisms of injury prevention. Environ. Health Perspect. 102 (suppl. 10), 65-68. 
Chance, B., Williams, G.R., 1956. The respiratory chain and oxidative phosphorylation. Adv. Enzymol. 17, 65-134.

Costantini, P., Chernyak, B.V., Petronilli, V., Bernardi, P., 1996. Modulation of the mitochondrial permeability transition pore by pyridine nucleotides and dithiol oxidation at two separate sites. J. Biol. Chem. 271, 6746-6751.

Ernster, L., Nordenbrand, K., 1967. Microsomal lipid peroxidation. In: Colowick, S.P., Kaplan, N.O. (Eds.), Methods in Enzymology. Academic Press, New York, pp. 574-580.

Fang, Q.-Z., Zhong, N., Zhang, Y., Zhou, Z.-N., 2004. Tetrandrine inhibits $\mathrm{Ca}^{2+}$-activated chloride channel in cultured human umbilical vein endothelial cells. Acta Pharmacol. Sim. 25, 327-333.

Gazotti, P., Malmstron, K., Crompton, M.A., 1979. Laboratory manual on transport and bioenergetics. In: Carafoli, E., Semenza, G. (Eds.), Membrane Biochemistry. Springer, New York, pp. 62-69.

Gornall, G., Bardawill, C.J., David, M.M., 1949. Determination of serum proteins by means of the biuret reaction, J. Biol. Chem. 177, 751-766.

Halestrap, A.P., Woodfield, K.Y., Connern, C.P., 1997. Oxidative stress, thiol reagents, and membrane potential modulate the mitochondrial permeability transition by affecting nucleotide binding to the adenine nucleotide translocase. J. Biol. Chem. 272, 3346-3354.

Hui, S.C., Chan, T.Y., Chen, Y.Y., 1996. Tetrandrine inhibits lipid peroxidation but lacks reactivity towards superoxide anion and hydrogen peroxide. Pharmacol. Toxicol. 78, 200-201.

Jang, B.-C., Lim, K.-J., Paik, J.-H., Cho, J.-W., Baek, W.-K., Suh, M.-H., Park, J.-B., Kwon, T.K., Park, J.-W., Kim, S.-P., Shin, D.-H., Song, D.-K., Bae, J.-H., Mun, K.-C., Suh, S.-I., 2004. Tetrandrine-induced apoptosis is mediated by activation of caspases and PKC- $\delta$ in U937 cells. Biochem. Pharmacol. 67, 1819-1829.

Jezek, P., Hlavatá, L., 2005. Mitochondria in homeostasis of reactive oxygen species in cell, tissues, and organism. Intern. J. Biochem. Cell Biol. 37, 2478-2503.

Jin, Q., Kang, C., Soh, Y., Sohn, N.W., Lee, J., Cho, Y.H., Baik, H.H., Kang, I., 2002. Tetrandrine cytotoxicity and its dual effect on oxidative stress-induced apoptosis through modulating cellular redox status in Neuro 2a mouse neuroblastoma cells. Life Sci. 71, 2053-2066.

Kamo, N., Muratsugu, M., Hongoh, R., Kobatake, N., 1979. Membrane potential of mitochondria measured with an electrode sensitive to tetraphenylphosphonium and relationship between proton electrochemical potential and phosphorylation potential in steady state. J. Membr. Biol. 49, 105-121.

Koh, S.B., Ban, J.Y., Lee, B.Y., Seong, Y.H., 2003. Protective effects of fangchinoline and tetrandrine on hydrogen peroxide-induced oxidative neuronal cell damage in cultured rat cerebellar granule cells. Planta Med. 69, 506-512.

Kowaltowski, A.J., Vercesi, A.E., 1999. Mitochondrial damage induced by conditions of oxidative stress. Free Radic. Biol. Med. 26, 463-472.

Kowaltowski, A.J., Castilho, R.F., Vercesi, A.E., 2001. Mitochondrial permeability transition and oxidative stress. FEBS Lett. 495, 12-15.

Lee, H.-C., Wei, Y.-H., 2000. Mitochondrial role in life and death of cell. J. Biomed. Sci. 7, 2-15.

Liu, Z., Xu, Z., Shen, W., Li, Y., Zhang, J., Ye, X., 2004. Effect of pharamacologic preconditioning with tetrandrine on subsequent ischemia/reperfusion injury in rat liver. World J. Surg. $28,620-624$.

Matsuno, T., Orita, K., Edashige, K., Kobuchi, H., Sato, E.F., Inouye, B., Inoue, M., Utsumi, K., 1990. Inhibition of active oxygen generation in guinea-pig neutrophils by biscoclaurine alkaloids. Biochem. Pharmacol. 39, 1255-1259.

McStay, G.P., Clarke, S.J., Halestrap, A.P., 2002. Role of critical thiol groups on the matrix surface of the adenine nucleotide translocase in the mechanism of the mitochondrial permeability transition pore. Biochem. J. 367 (Pt 2), 541-548.

Murphy, M.P., Smith, R.A.J., 2000. Drug delivery to mitochondria: the key to mitochondrial medicine. Adv. Drug Deliv. Rev. 41, 235-250.

Oh, S.-H., Lee, B.-H., 2003. Induction of apoptosis in human hepatoblatoma cells by tetrandrine via caspase-dependent bid cleavage and cytochrome c release. Biochem. Pharmacol. 66, 725-731.
O’Rourke, B., 2000. Pathophysiological and protective roles of mitochondrial ion channels. J. Physiol. 529, 23-36.

Pedersen, P.L., 2000. Mitochondrial events in the life and death of animal cells. A brief overview. J. Bioenerg. Bomembr. 31, 291-304.

Rajdev, S., Reynolds, I.J., 1993. Calcium green-5N, a novel fluorescent probe for monitoring high intracellular free $\mathrm{Ca}^{2+}$ concentration associated with glutamate excitotoxicity in cultured rat brain neurons. Neurosc. Lett. 162, 149-152.

Ren, Z.J., Zeng, D.Y., Zhang, X.H., Jiao, K.R., Wang, H.L., 1995. Protective effects of tetrandrine on experimental myocardial ischaemia and reperfusion injury in rabbits. Chin. J. Pharmacol. Toxicol. 9, 303304.

Sassa, H., Takaish, Y., Terada, H., 1990. The triterpene celastrol as a very potent inhibitor of lipid peroxidation in mitochondria. Biochem. Biophys. Res. Commun. 172, 890-897.

Sekiya, N., Hikiami, H., Yokoyama, K., Kouta, K., Sakakibara, I., Shimada, Y., Terasawa, K., 2005. Inhibitory effects of Stephania tetrandra $\mathrm{S}$. Moore on free radical-induced lysis of rat red blood cells. Biol. Pharm. Bull. 28, 667-670.

Seow, W.K., Ferrante, A., Li, S.Y., Thong, Y.H., 1988. Antiphagocytic and antioxidant properties of plant alkaloide tetrandrine. Int. Arch. Allergy Appl. Immunol. 85, 404-409.

Shen, Y.C., Chen, C.F., Wang, S.Y., Sung, Y.J., 1999a. Impediment to calcium influx and reactive oxygen production accounts for the inhibition of neutrophil Mac-1 up-regulation and adhesion by tetrandrine. Mol. Pharmacol. 55, 186-193.

Shen, Y.C., Chen, C.F., Sung, Y.J., 1999b. Tetrandrine ameliorates ischaemia-reperfusion injury of rat myocardium through inhibition of neutrophil priming and activation. Br. J. Pharmacol. 128, 1593-1601.

Shen, Y.C., Chou, C.J., Chiou, W.F., Chen, C.F., 2001. Anti-inflammatory effects of the partially purified extract of radix Stephaniae tetrandrae: comparative studies of its active principles tetrandrine and fangchinoline on human polymorphonuclear leukocyte functions. Mol. Pharmacol. 60, 1083-1090.

Shi, X., Mao, Y., Saffiotti, U., Wang, L., Rojanasakul, Y., Leonard, S.S., Vallyathan, V., 1995. Antioxidant activity of tetrandrine and its inhibition of quartz-induced lipid peroxidation. J. Toxicol. Environ. Health 46, 233-248.

Vanden Hoek, T.L., Becker, L.B., Shao, Z., Li, C., Schumacker, P.T., 1998. Reactive oxygen species released from mitochondria during brief hypoxia induce preconditioning in cardiomyocytes. J. Biol. Chem. 273, 18092-18098.

Vicente, J.A.F., Santos, M.S., Vercesi, A.E., Madeira, V.M.C., 1998. Comparative effects of the herbicide dinitro-o-cresol on mitochondrial bioenergetics. Pestic. Sci. 54, 43-51.

Wang, G., Lemos, J.R., Ladecola, C., 2004. Herbal alkaloid tetrandrine: from an ion channel blocker to inhibitor of tumour proliferation. Trends Pharmacol. Sci. 25, 120-123.

Wu, M.N., McKown, L.A., Gopaul, V.S., 2004. In-vitro metabolism of isotetrandrine, a bisbenzylisoquinoline alkaloid, in rat hepatic S9 fraction by high-performance liquid chromatography-atmospheric pressure ionisation mass spectrometry. J. Pharm. Pharmacol. 56, $749-755$.

Yan, C., Xin-Ming, Q., Li-Kun, G., Lin-Lin, L., Fang-Ping, C., Ying, X., Xiong-Fei, W., Xiang-Hong, Li., Jin, R., 2006. Tetrandrine-induced apoptosis in rat primary hepatocytes is initiated from mitochondria: Caspases and Endonuclease G (Endo G) pathway. Toxicology 218, 112.

Ye, J., Ding, M., Zhang, X., Rojanasakul, Y., Shi, X., 2000. On the role of hydroxyl radical and the effect of tetrandrine on nuclear factor-kappa $\mathrm{B}$ activation by phorbol 12-myristate 13 -acetate. Ann. Clin. Lab. Sci. $30,65-71$.

Yu-Jen, C., 2002. Potential role of tetrandrine in cancer therapy. Acta Pharmacol. Sin. 23, 1102-1106.

Zernig, G., Graziadei, I., Moshammer, T., Zech, C., Reider, N., Glossmann, H., 1990. Mitochondrial $\mathrm{Ca}^{2+}$ antagonist binding sites are associated with an inner mitochondrial membrane anion channel. Mol. Pharmacol. 38, 362-369. 